\title{
ANALISIS REAKSI INVESTOR SEBAGAI DAMPAK COVID-19 PADA SEKTOR PERBANKAN DI INDONESIA
}

\author{
Crescentiano Agung Wicaksono ${ }^{1}$, Rahandhika Ivan Adyaksana ${ }^{2}$ \\ ${ }^{1}$ Akademi Akuntansi YKPN, Yogyakarta, Indonesia \\ ${ }^{2}$ Universitas PGRI Yogyakarta, Yogyakarta, Indonesia \\ Email: crescentiano.agung@gmail.com
}

\begin{abstract}
This study aims to determine the abnormal return and volume of stock trading transaction due to the Covid19 pandemic. This research was conducted at banking sector companies listed on the Indonesia Stock Exchange. The research method uses a quantitative approach with the secondary data obtained from Yahoo Finance. This research is an event study of stock prices and trading volume 20 days before and after the announcement of Covid-19 as a global pandemic. Data analysis was performed using Wilcoxon Signed Rank. The results showed there were significant differences in abnormal returns and transaction volume activity before and after the announcement of Covid-19 as a global pandemic. The test results show an overview of the volatility of stock prices and trading volumes that experienced sharp fluctuations during the pandemic. Therefore, investors should also diversify in real assets other than financial asset and consider carefully any investment decisions taken.
\end{abstract}

Keywords: abnormal return, Covid-19, transaction volume

\section{ABSTRAK}

Penelitian ini bertujuan untuk mengetahui abnormal return dan volume transaksi perdagangan saham karena adanya pandemic Covid-19. Penelitian ini dilakukan pada perusahaan sektor perbankan yang terdaftar di Bursa Efek Indonesia. Metode penelitian menggunakan pendekatan kuantitatif dengan data sekunder yang diperoleh dari yahoo finance. Penelitian ini merupakan event study dari harga saham dan volume perdagangan saham 20 hari sebelum dan sesudah pengumuman Covid-19 sebagai pandemi global. Analisis data dilakukan dengan menggunakan Wilcoxon Signed Rank Test. Hasil penelitian menunjukkan terdapat perbedaan yang signifikan abnormal return dan aktivitas volume transaksi sebelum dan sesudah pengumuman Covid-19 sebagai pandemi global. Hasil pengujian menunjukkan gambaran tentang volatilitas harga saham dan trading volume yang mengalami fluktuasi tajam pada masa pandemi. Oleh karena itu, hendaknya investor juga melakukan diversifikasi di real assets selain financial asset, serta mempertimbangkan secara matang untuk setiap keputusan investasi yang diambil.

Kata kunci: abnormal return, Covid-19, volume transaksi

KETERANGAN ARTIKEL

Riwayat Artikel: diterima: 30 Juli 2020; direvisi: 25 November 2020; disetujui: 2 Desember 2020

Klasifikasi JEL: G14

Cara Mensitasi: Wicaksono, C.A., dan Adyaksana, R.I. (2020). Analisis Reaksi Investor sebagai Dampak Covid-19 pada Sektor Perbankan di Indonesia. JIAFE (Jurnal IImiah Akuntansi Fakultas Ekonomi), 6(2), 129138. https://doi.org/10.34204/jiafe.v6i2.2227

Copyright@2020. JIAFE (Jurnal Akuntansi Ilmiah Fakultas Ekonomi) Universitas Pakuan

\section{PENDAHULUAN}

Virus corona atau Covid-19 diidentifikasi untuk pertama kali pada 8 Desember 2019 di Wuhan, China (World Health Organization,
2020). Penyebaran virus ini sangat cepat, sehingga dalam waktu yang singkat virus ini dapat menyebar ke seluruh dunia termasuk di Indonesia. Fenomena ini tidak hanya 
berdampak parah pada perekonomian di seluruh dunia, akan tetapi semua masyarakat juga terpengaruh, yang telah menyebabkan perubahan dramatis dalam cara berbisnis dan perilaku konsumen (Donthu dan Gustafsson, 2020). Pada tanggal 11 Maret 2020, terkonfirmasi 119.179 kasus Covid-19 di 118 Negara hingga pada akhirnya ditetapkan sebagai pandemi global oleh organisasi kesehatan dunia (WHO) (World Health Organization, 2020). Indonesia melalui Gugus Tugas Percepatan Penanganan Coronavirus Disease 2019 (COVID-19) melakukan berbagai upaya guna mencegah penyebaran virus, misalnya dengan melakukan work from home, physical distancing, meliburkan sekolah, menggunakan masker, dan berbagai protokol kesehatan lainnya. Gugus tugas ini bertugas untuk mengkoodinasikan dan mengkominikasikan kegiatan antar lembaga dalam upaya menanggulangi dan meminimalisasi dampak penyakit virus Covid19 di Indonesia.

Wabah Covid-19 yang menyebar begitu cepat memberikan dampak negatif terhadap perekonomian secara global, tak terkecuali di Indonesia. Pada triwulan pertama tahun 2020, sejumlah negara yang menjadi mitra dagang Indonesia mengalami pertumbuhan perekonomian yang negatif: Hongkong $-8,9$, Singapura -2,2, China -6,8, dan Uni Eropa -2,7. Secara agregat, Indonesia mengalami penurunan perekonomian cukup signifikan, yaitu dari 4,97 di kuartal 4 tahun 2019 menjadi hanya tumbuh 2,97 pada kuartal pertama 2020 (Sakti, 2020). Kondisi ini juga berpengaruh pada pasar modal. Tercatat sejak awal tahun hingga penutupan perdagangan 20 Maret 2020, Indeks Harga Saham Gabungan (IHSG) turun sebesar 33,41\% (Hadinata, 2020).

Penurunan perekonomian secara kumulatif merupakan dampak Covid-19 yang berdampak pada berbagai sektor. Industri perbankan sendiri terancam mengalami tiga risiko akibat Covid-19; pertama, risiko kredit yang akan terjadi ketika sektor UMKM tidak mampu membayar kewajibannya, kedua risiko pasar yang muncul karena pelemahan nilai tukar, dan ketiga, likuiditas yang akan karena debitur mengalami kesusahan dalam usaha atau pendapatan (Elena, 2020). Oleh karena itu, perlu dilakukan upaya untuk menghindari resiko tersebut dan menjaga kesehatan industri perbankan.

Harga saham dapat mencerminkan kondisi keuangan suatu perusahaan (Hidayat dan Topowijono, 2018). Harga saham suatu perusahaan terbentuk dari permintaan dan penawaran investor akan saham tersebut. Harga saham akan menjadi tinggi apabila banyak investor yang melakukan permintaan atas saham tersebut, demikian juga sebaliknya. Investor memerlukan informasi yang komprehensif atas suatu perusahaan untuk mengurangi risiko yang akan diterima sebelum melakukan keputusan dalam investasi. Selain itu, investor juga dapat mempertimbangkan volume perdagangan saham dalam mengambil keputusan investasi. Volume perdagangan menunjukkan jumlah lembar saham yang ditransaksikan di pasar modal selama periode waktu tertentu (Tandelilin, 2010)

Menurut Suryanto dan Muhyi (2017), reaksi pasar terhadap suatu informasi juga tercermin dalam volatilitas volume perdagangan saham. Saham yang aktif dapat dilihat dari volume perdagangan yang besar. Akan tetapi, harga saham yang terlalu tinggi dapat menurunkan volume perdagangan saham yang terjadi di pasar karena kemampuan beberapa investor untuk membeli saham juga semakin kecil.

Berdasarkan penjelasan di atas bahwa Covid-19 memberikan dampak terhadap perekonomian secara global, penelitian ini dilakukan untuk melihat apakah terdapat perbedaan abnormal return dan volume transaksi perdagangan saham yang signifikan sebelum dan sesudah pengumuman Covid-19 sebagai pandemi global oleh WHO, yaitu 11 Maret 2020. Penelitian yang dilakukan oleh Nurmasari (2020) dengan obyek PT. Ramayana Lestari Sentosa, Tbk menunjukkan terdapat 
perbedaan yang signifikan pada harga saham dan volume transaksi saham sebelum dan sesudah diumumkannya kasus covid-19 di Indonesia, yakni 2 Maret 2020. Penelitian yang dilakukan oleh Haryanto (2020) menunjukkan bahwa setiap ada kenaikan 1\% kasus Covid-19 akan menyebabkan koreksi terhadap Indeks Harga Saham Gabungan sebesar 0,03\%. Penelitian yang dilakukan Nurmasari (2020) terkait dampak Covid-19 terhadap volume dan harga saham baru dilakukan pada satu perusahaan saja, yakni PT. Ramayana Lestari Sentorsa, Tbk. Sebagai keterbaruan, penelitian ini dilakukan untuk melihat dampak Covid-19 pada abnormal return dan volume transaksi saham pada sektor perbankan untuk melihat dampak Covid-19 secara lebih komprehensif dan general. Sektor perbankan yang terdaftar di BEI menjadi sampel dalam penelitian ini, karena sektor perbankan menjadi salah satu sektor yang mendapatkan dampak besar dari adanya Covid-19 dan harus segera menyesuaikan diri untuk menghindari ketidakstabilan lebih lenjut (Bidari dan Nurviana, 2020). Selain itu, penelitian ini menggunakan cut-off 11 Maret 2020 pada event study, yaitu ketika WHO mengumumkan wabah Covid-19 sebagai pandemi global, sedangkan penelitian - penelitian sebelumnya menggunakan cut-off 2 Maret 2020, yaitu ketika kasus Covid-19 pertama kali terjadi di Indonesia. Alasan penelitian ini menggunakan cut-off 11 Maret 2020 adalah karena industri perbankan adalah industri yang mempunyai kaitan erat dengan kondisi perokonomian global. Oleh karena itu, penulis meyakini pengumuman yang dilakukan oleh WHO yang menyatakan bahwa Covid-19 sebagai pandemi global lebih relevan menjadi cut-off pada penelitian ini.

\section{KAJIAN LITERATUR DAN PENGEMBANGAN HIPOTESIS}

\section{Event Study}

Menurut Peterson (1989), event study merupakan salah satu metode yang dapat digunakan untuk mengamati dan menganalisis dampak suatu kejadian pada volume dan harga saham di pasar modal. Harga saham suatu perusahaan di sekitar kejadian tersebut menjadi obyek yang diamati. Menurut Kritzman (1994), hubungan tingkat pengembalian (return) dengan suatu peristiwa dapat diukur menggunakan metode event study. Sedangkan menurut Mackinlay (1997), data-data pasar keuangan dapat menjadi ukuran untuk melakukan analisis dampak suatu peristiwa yang spesifik dalam metode event study, biasanya tercermin dalam volume dan harga saham

Pada penelitian ini, peristiwa yang akan diteliti adalah pada saat pengumuman Covid19 sebagai pandemi global, yaitu 11 Maret 2020. Pada event study, akan diambil jangka waktu tertentu sebelum dan sesudah peristiwa, biasanya dengan jangka waktu yang sama. Hal ini dilakukan untuk memperoleh perbandingan dari objek yang diteliti dan dapat melihat pengaruh peristiwa terhadap variabel yang diteliti. Event study digunakan pada penelitian ini dengan maksud untuk melihat hubungan pengumuman Covid-19 sebagai pandemi global dengan return saham dan volume transaksi saham sebelum dan sesudah pengumuman tersebut.

\section{Teori Sinyal}

Ross (1977) dalam teori sinyal menyatakan bahwa tanda perusahaan telah beroperasi dengan baik dapat tercermin dalam laporan keuangan yang baik pula. Informasi yang tersaji dalam laporan keuangan merupakan unsur penting bagi investor dan pelaku bisnis dalam membuat keputusan karena menyajikan keterangan, catatan keadaan masa lalu, saat ini maupun keadaan yang akan datang. Informasi ini akan direspons oleh pasar sebagai suatu sinyal good news atau bad news. Informasi perusahaan yang mengindisikasikan sinyal good news, maka nantinya akan meningkatkan harga saham perusahaan tersebut, begitu sebaliknya. Perlu 
diketahui bahwa investor bereaksi terhadap pasar saham tidak hanya berdasarkan laporan keuangan yang dikeluarkan oleh perusahaan, melainkan juga menggunakan informasi lain yang berdampak pada kondisi perusahaan.

Wabah Covid-19 secara keseluruhan memberikan dampak buruk bagi sebagian besar perusahaan. Banyak perusahaan yang mengalami penurunan keuntungan, bahkan mengalami kerugian di masa pandemi Covid19. Kondisi seperti ini tentu menjadi bad news bagi investor karena kondisi perusahaan menjadi tidak tentu dan tidak stabil. Kondisi ini akan direspons secara negatif oleh investor, hingga pada akhirnya akan menurunkan harga saham perusahaan.

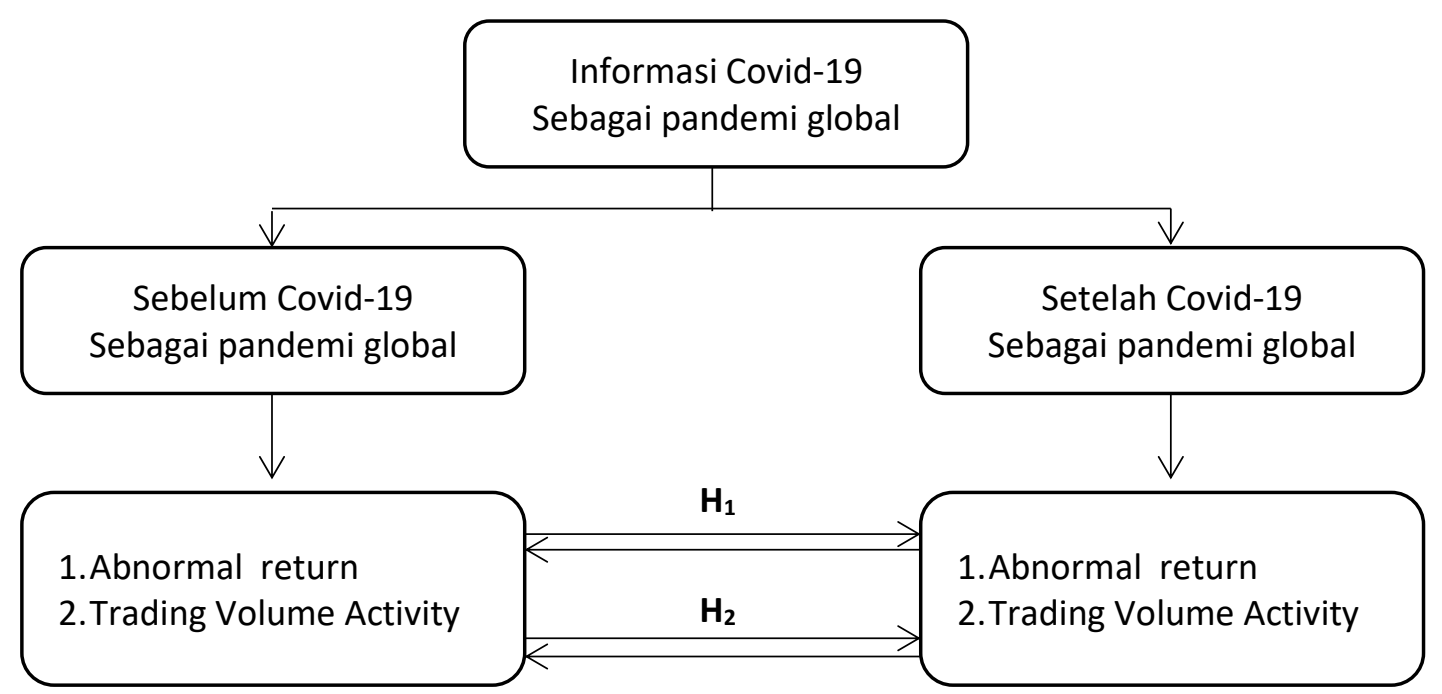

Gambar 1. Kerangka Pemikiran

\section{Pengembangan Hipotesis}

Saat wabah virus terjadi, tidak ada yang mampu memprediksi secara akurat kapan wabah tersebut berakhir. Sebagai efek jangka panjang, virus akan berdampak buruk pada kesehatan dan pasar saham. Beberapa bukti literatur menunjukkan bahwa Covid-19 memiliki dampak signifikan pada pasar keuangan di seluruh dunia. Indikator dampak Covid-19 terhadap pasar keuangan dapat dilihat di berbagai pasar keuangan dunia, misalnya tingkat perdagangan indeks Dow and the $S \& P$ turun secara signifikan sebagai respons atas pandemi Covid-19 (Sansa, 2020).

Baret, dkk. (2020) membahas secara rinci dampak Covid-19 terhadap pasar keuangan dan bank. Dalam penelitian tersebut, mereka berpendapat bahwa Covid19 memiliki efek signifikan terhadap pasar keuangan, seperti jatuhnya saham, minyak, ekuitas, dan obligasi di seluruh dunia. Hal ini menjadi bukti bahwa Covid-19 telah memberikan dampak serius dalam perekonomian global. Penelitian lain yang dilakukan oleh Chowdhury dan Abedin (2020) mengukur dampak Covid-19 pada pasar saham Amerika Serikat. Pasar saham AS bereaksi negatif secara signifikan terhadap kanaikan kasus yang dikonfirmasi dan kasus kematian akibat Covid-19. Ketidakpastian Covid-19 dan ekonomi membuat pasar saham sangat fluktuatif dan impulsif.

Penelitian dampak Covid-19 di Indonesia telah dilakukan oleh Nurmasari (2020), yang menemukan bahwa harga saham PT Ramayana Lestari Santosa, Tbk mengalami perbedaan yang signifikan pada sebelum dan sesudah diumumkannya kasus Covid-19 pertama di Indonesia, yaitu pada 2 Maret 2020. Dalam penelitiannya, ditemukan bahwa rata-rata harga saham mengalami penurunan, yaitu dari Rp1.052,74 sebelum pengumuman 
Covid-19 di Indonesia menjadi Rp628,48 setelah pengumuman. Penelitian lain yang dilakukan oleh Kusnandar dan Bintari (2020) juga menunjukkan bahwa terdapat perbedaan signifikan abnormal return pada perusahaan yang termasuk dalam indeks LQ-45 tahun 2020 selama masa pandemi. Penelitian ini menggunakan proksi abnormal return untuk melihat reaksi investor yang tercermin dalam harga saham suatu perusahaan. Berdasarkan penjelasan di atas, penulis menyusun hipotesis sebagai berikut:

$\mathrm{H}_{1}$ : terdapat perbedaan signifikan abnormal return sebelum dan sesudah pengumuman Covid-19 sebagai pandemi global pada sektor perbankan di Indonesia.

Volume transaksi saham adalah jumlah saham perusahaan yang diperjual belikan di pasar saham pada periode tertentu. Minat investor dapat tercermin dalam besar atau kecilnya volume transaksi saham. Dalam penelitiannya, Nurmasari (2020) menemukan bahwa terdapat perbedaan yang signifikan volume transaksi PT. Ramayana Lestari Sentosa, Tbk. sebelum dan sesudah diumumkannya kasus pertama kasus pertama Covid-19 di Indonesia. Dalam penelitian tersebut, ditemukan bahwa rata-rata volume transaksi sebelum pengumuman adalah 5.454.712,90 sedangkan rata-rata volume transaksi setelah pengumuman adalah 16.060.709,69. Kekhawatiran dan ketakutan investor bahwa investor akan mengalami kerugian yang lebih banyak sebagai akibat Covid-19 mendorong mereka untuk menjual saham. Namun, ada alasan lain yang dapat menjelaskan peristiwa ini, yaitu banyak investor memanfaatkan peluang membeli saham yang harganya telah menjadi lebih murah. Penelitian yang dilakukan oleh Saputro (2020) juga menunjukkan bahwa terdapat kenaikan volume perdagangan saham pada indeks Jakarta Islamic Indek (JII) secara signifikan setelah diumumkan Covid-19 di Indonesia. Penelitian lain yang dilakukan oleh
Dewi dan Masithoh (2020) juga menunjukkan bahwa terdapat perbedaan signifikan trading volume sebelum dan sesudah Covid-19 pada IHSG

Penelitan trading volume activity sebelum dan sesudah stock split pernah dilakukan Utami (2017). Dalam penelitiannya, ditemukan bahwa terdapat perbedaan signifikan volume transaksi saham sebelum dan sesudah pengumuman stock split. Hasil ini disebabkan karena investor tertarik dengan harga saham yang menjadi lebih murah dibandingkan harga saham sebelum stock split.

Mengacu pada harga saham perusahaan, tercatat bahwa laju IHSG turun 27,95\% sepanjang kuartal 1/2020 (Pratomo, 2020). Berdasarkan penjelasan di atas dan kondisi ekonomi bahwa harga saham cenderung turun akibat pandemi Covid-19, penulis memprediksi akan terjadi peningkatan volume transaksi saham. Oleh karena itu, penulis mengajuka hipotesis sebagai berikut:

$\mathrm{H}_{2}$ : terdapat perbedaan signifikan volume transaksi sebelum dan sesudah pengumuman Covid-19 sebagai pandemi global pada sektor perbankan di Indonesia.

\section{METODE PENELITIAN}

Metode penelitian yang digunakan adalah kuantitatif dengan jenis penelitian analisis statistik deskriptif dan event study. Menurut MacKinlay (1997), event study adalah metodologi penelitian dengan data pasar keuangan yang digunakan untuk mengukur dampak suatu event secara spesifik terhadap nilai perusahaan yang tercermin dalam volume transaksi dan harga saham. Perusahaan perbankan terdaftar di BEI serta saham perusahaan yang aktif diperdagangkan selama 20 hari sebelum dan sesudah pengumuman Covid-19 dinyatakan sebagai pandemi secara global oleh WHO merupakan sampel penelitian. Data berupa harga saham dan volume transaksi diperoleh melalui website yahoo finance. Data harga saham 
yang digunakan untuk pengukuran dalam penelitian ini adalah closing price.

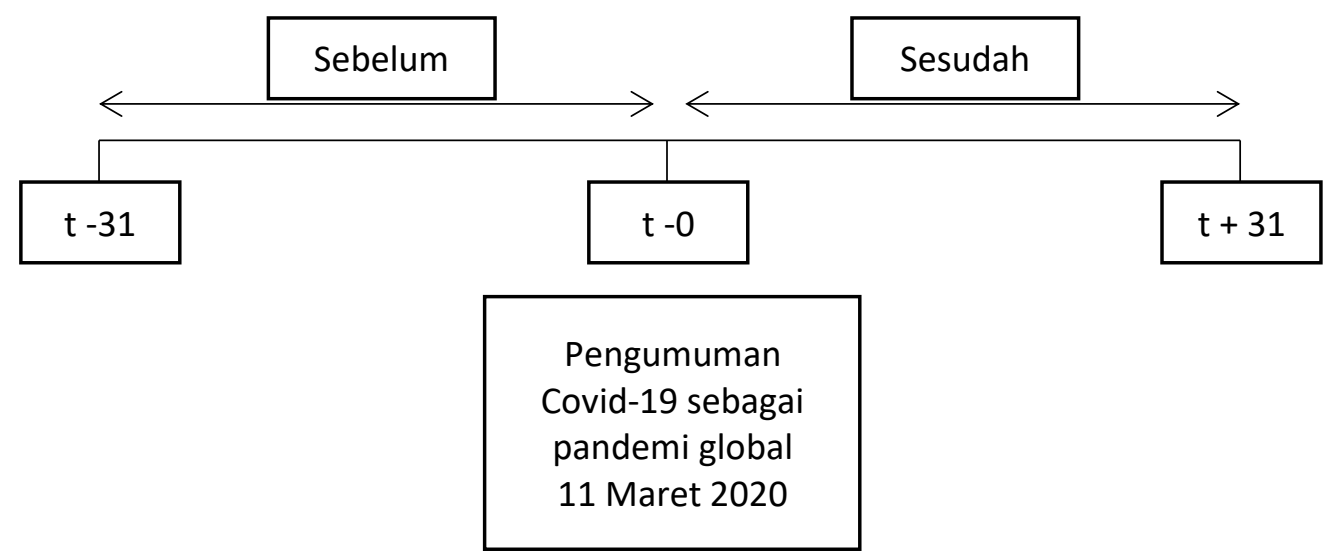

\section{Gambar 2. Event Period}

Trading Volume Activity (TVA) Event window merupakan periode digunakan untuk mengukur perubahan pengamatan yang digunakan untuk volume perdagangan saham. Sedangkan menghitung abnormal return dan volume perhitungan abnormal return dilakukan transaksi saham. Rumus Trading Volume selama event window, yaitu masing-masing 20 Activity (TVA) adalah sebagai berikut (Husnan, hari sebelum dan sesudah 11 Maret 2020. 2005).

$$
T V A=\frac{\sum \text { saham perusahaan } j \text { yang diperdagangkan pada waktu } t}{\sum \text { saham perusahaan } j \text { yang berada pada waktu } t}
$$

Berikut beberapa langkah untuk menghitung abnormal return (Hapsoro dan Husain, 2019). Pertama, menghitung actual return saham selama event period.

$$
R_{i t}=\frac{\left(P_{i t}-P_{i t-1}\right)}{P_{i t-1}}
$$

\section{Keterangan:}

$\mathrm{R}_{\mathrm{it}}=$ Return saham i pada hari $\mathrm{t}$

$P_{i t}=$ Harga saham i pada hari $t$

$\mathrm{P}_{\mathrm{it}-1}=$ Harga saham i pada hari $\mathrm{t}-1$

Kedua, menghitung expected return saham harian selama event period.

$$
E\left(R_{i t}\right)=R_{m t}
$$

Keterangan:

$\mathrm{E}\left(\mathrm{R}_{\mathrm{it}}\right)=$ Expected return saham $\mathrm{i}$

$\mathrm{R}_{\mathrm{mt}} \quad=$ Return pasar pada hari $\mathrm{t}$

$$
R_{m t}=\frac{\left(I H S D G_{t}-P_{t-1}\right)}{I H S G_{t-1}}
$$

Keterangan:

$\mathrm{R}_{\mathrm{mt}} \quad=$ Return pasar pada hari $\mathrm{t}$

$\mathrm{IHSG}_{\mathrm{t}}=$ Index harga saham gabungan pada harit

$\mathrm{IHSG}_{\mathrm{t}-1}=$ Index harga saham gabungan pada hari t-1

Ketiga, menghitung abnormal return saham selama event period

$$
A R_{i t}=R_{i t}-E\left(R_{i t}\right)
$$


Keterangan:

$\mathrm{AR}_{\text {it }} \quad=$ Abnormal return saham $\mathrm{i}$ pada hari $\mathrm{t}$

$\mathrm{R}_{\mathrm{it}} \quad=$ Actual return saham i pada hari $\mathrm{t}$

$\mathrm{E}\left(\mathrm{R}_{\mathrm{it}}\right) \quad=$ Expected return saham $\mathrm{i}$ pada hari $\mathrm{t}$

Karena penelitian ini mengasumsikan bahwa expected return semua sama sama dengan expected return, maka diperoleh rumus sebagai berikut:

$$
A R_{i t}=R_{i t}-R_{m t}
$$

Keterangan :

$\mathrm{AR}_{\text {it }} \quad=$ Abnormal return saham i pada hari $\mathrm{t}$

$\mathrm{R}_{\mathrm{it}} \quad=$ Actual return saham i pada hari $\mathrm{t}$

$\mathrm{R}_{\mathrm{mt}} \quad=$ Return pasar pada hari $\mathrm{t}$

Statistik non-parametrik Wilcoxon Signed Rank Test digunakan untuk pengujian hipotesis. Pengujian ini digunakan untuk mengetahui ada atau tidaknya perbedaan abnormal return dan volume perdagangan saham sebelum dan sesudah penetapan Covid19 sebagai pandemi global. $\mathrm{H}_{0}$ diterima apabila $p$-value $>0,05$, artinya tidak terdapat beda signifikan abnormal return dan volume perdagangan sebelum dan sesudah pengumuman Covid-19 sebagai pandemi global. $\mathrm{H}_{0}$ ditolak apabila $p$-value $\leq 0,05$. Artinya ada beda signifikan abnormal return dan volume perdagangan sebelum dan sesudah penetapan Covid-19 sebagai pandemi global.

\section{HASIL DAN PEMBAHASAN}

Kasus Covid-19 pertama kali terjadi di Wuhan, China pada akhir Desember 2019. Beberapa bulan kemudian kasus terkait virus ini mulai menyebar dan menginfeksi masyarakat di berbagai negara. Tujuan dilakukannya penelitian ini untuk meninjau reaksi investor pada pasar saham Indonesia, khususnya sektor perbankan di sekitar peristiwa saat WHO menetapkan Covid-19 sebagai pandemi global, yaitu 20 hari sebelum dan 20 hari sesudah penetapan. Tabel 1 menyajikan hasil statistik deskriptif abnormal return dan volume perdagangan saham.

Terdapat 41 perusahaan sektor perbankan yang menjadi sampel penelitian. Tabel 1 menyajikan nilai rata-rata (mean) abnormal return adalah 0,0045519 sebelum pengumuman Covid-19 sebagai pandemi global dan setelah pengumuman rata-rata abnormal return turun menjadi -0,0010547. Artinya terjadi penurunan abnormal return sebesar 0,0056066. Nilai rata-rata Trading Volume Activity (TVA) pada tabel tersebut sebelum pengumuman Covid-19 sebagai pandemi global adalah 0,0003388, sedangkan rata-rata TVA sesudah pengumuman adalah 0,0005987 . Artinya teradapat kenaikan TVA sebesar 0,0002599.

Tabel 1. Deskripsi Variabel

\begin{tabular}{l|c|c|c}
\hline \multicolumn{1}{c|}{ Variabel } & $\boldsymbol{N}$ & Mean & Standar Deviasi \\
\hline $\begin{array}{l}\text { Rata-rata Abnormal Return } \\
\text { Sebelum }\end{array}$ & 41 & 0,0045519 & 0,0096207 \\
\hline $\begin{array}{l}\text { Rata-rata Abnormal Return } \\
\text { Sesudah }\end{array}$ & 41 & $-0,0010547$ & 0,0082740 \\
\hline Rata-rata TVA Sebelum & 41 & 0,0003388 & 0,0004985 \\
\hline Rata-rata TVA Sesudah & 41 & 0,0005987 & 0,0011678 \\
\hline
\end{tabular}

Statistik non-parametrik Wilcoxon Signed Rank Test merupakan teknik analisis data yang digunakan dalam penelitian ini. Teknik ini dapat digunakan untuk menguji hipotesis pada data yang tidak terdistribusi normal. Tabel 2 menyajikan hasil pengolahan data dengan menggunakan SPSS versi 25 . 
Tabel 2. Hasil Pengujian Wilcoxon Signed Rank Test

\begin{tabular}{l|c|c}
\hline & $\begin{array}{c}\text { AR Sesudah-AR } \\
\text { Sebelum }\end{array}$ & $\begin{array}{c}\text { TVA Sebelum- } \\
\text { TVA Sesudah }\end{array}$ \\
\hline Z & $-3,143$ & $-2,611$ \\
\hline Asymp. Sig. (2-tailed) & 0,002 & 0,009 \\
\hline
\end{tabular}

Pada tabel 2 menyajikan nilai rata-rata hasil pengujian Sig. (2-tailed) untuk abnormal return sebesar 0,002, yaitu kurang dari 0,05. Berdasarkan hasil tersebut maka dapat disimpulkan bahwa $\mathrm{Ha}$ diterima, berarti diperoleh bukti adanya beda signifikan ratarata abnormal return sebelum dan sesudah penetapan Covid-19 sebagai pandemi global. Pandemi Covid-19 memberikan dampak buruk terhadap operasional perusahaan, hingga mengalami penurunan yang tajam pada laba perusahaan bahkan mengalami kerugian. Kondisi perusahaan yang tidak stabil menjadi sinyal negatif bagi investor yang pada akhirnya mengakibatkan harga saham perusahaan mengalami penurunan yang sangat signifikan.

Hasil ini mendukung penelitian Nurmasari (2020) yang menunjukkan bahwa terjadi penurunan harga saham yang signifikan dibanding sebelum munculnya pandemi Covid19 di Indonesia. Hasil penelitian ini juga mendukung temuan penelitian Chowdhury dan Abedin (2020) yang menemukan bahwa pasar saham Amerika Serikat bereaksi negatif terhadap kasus Covid-19. Artinya, semakin tinggi kasus Covid-19 yang terjadi, pasar saham Amerika Serikat yang diukur menggunakan abnormal return mengalami penurunan. Kecenderungan penurunan pasar saham ini disebabkan oleh kepanikan investor tehadap perekomian global sehingga hal ini membuat harga saham perusahaan cenderung menjadi turun.

Berdasarkan hasil pengujian pada tabel 2, rata-rata hasil pengujian Sig. (2 tailed) untuk Trading Volume Activity (TVA) adalah 0,009, yaitu kurang dari 0,05 , sehingga diperoleh kesimpulan bahwa Ha diterima. Hasil tersebut membuktikan bahwa terdapat perbedaan yang signifikan antara rata-rata TVA sebelum dan sesudah pengumuman Covid-19 sebagai pandemi global. Hasil pengujian sesuai dengan temuan penelitian yang telah dilakukan oleh Nurmasari (2020) yang menunjukkan adanya perbedaan volume transaksi saham yang cukup signifikan antara sebelum dan sesudah kasus Covid-19 pertama di Indonesia. Nurmasari (2020) berargumen bahwa peningkatan volume ini terjadi karena mayoritas investor akan menjual saham yang dimilikinya akibat kekhawatiran risiko untuk mengalami kerugian yang lebih besar apabila terus memiliki saham perusahaan tersebut.

Terjadi perbedaan sebelum dan sesudah pengumuman covid-19 sebagai pandemic global terhadap rata-rata Trading Volume Activity (TVA). Rata-rata TVA mengalami peningkatan setelah pengumuman tersebut. Fenomena ini terjadi karena banyak investor khawatir akan mengalami kerugian yang besar, sehingga banyak yang menjual saham mereka. Selain alasan tersebut, harga saham perusahaan yang cenderung turun justru dimanfaatkan oleh para investor untuk memperoleh harga yang murah untuk pembelian saham suatu perusahaan berharap akan mendapatkan keuntungan ketika harga saham kembali naik. Kondisi itulah yang membuat volume transaksi saham menjadi tinggi.

\section{PENUTUP}

Ada beberapa kesimpulan pada penelitian ini. Berdasarkan uji Wilcoxon Signed Rank Test dan analisis data yang telah dilakukan. Kesimpulan pertama adalah diperoleh perbedaaan sebelum dan sesudah diumumkannya Covid-19 sebagai suatu pandemi secara global terhadap rata-rata abnormal return. Abnormal return setelah pengumumuman tersebut mengalami penurunan. Hal ini disebabkan karena adanya 
kepanikan beberapa investor terhadap perekonomian secara global, sehingga ada kecenderungan investor untuk menjual saham dan berakibat pada penurunan harga saham. Kesimpulan kedua adalah terjadi peningkatan rata-rata Trading Volume Activity (TVA) setelah pengumuman covid-19 sebagai pandemic global. Fenomena ini terjadi karena banyak investor khawatir akan mengalami kerugian yang besar, sehingga banyak yang menjual saham mereka. Selain alasan tersebut, harga saham perusahaan yang cenderung turun justru dimanfaatkan oleh para investor untuk memperoleh harga yang murah untuk pembelian saham suatu perusahaan berharap akan mendapatkan keuntungan ketika harga saham kembali naik. Kondisi itulah yang membuat volume transaksi saham menjadi tinggi.

Periode penelitian ini menggunakan 20 hari sebelum dan sesudah pandemi covid 19 sehingga hasil yang diperoleh adalah hasil uji beda dalam periode jangka pendek dan tidak melihat pengaruhnya dalam jangka panjang. Saran penelitian selanjutnya dapat meneliti tentang pengaruh uji beda menggunakan periode jangka panjang supaya dapat melihat perbedaan secara lebih komprehensif.

Hasil penelitian ini mempunyai implikasi terhadap beberapa pihak yang terkait. Pertama, dengan adanya hasil bahwa harga saham cenderung turun, maka perusahaan hendaknya melakukan terobosan baru di era new normal supaya kinerja perusahaan tetap terjaga, misalnya pelayanan online perbankan semakin ditingkatkan. Dengan kinerja yang baik diharapkan kepercayaan investor terhadap perusahaan tetap terjaga dan harga saham akan kembali naik. Kedua, investor hendaknya dapat melakukan pertimbangan secara matang untuk setiap keputusan yang akan diambil, baik membeli dan menjual saham, serta tidak melakukan panic selling apalagi tanpa pertimbangan yang komprehensif. Hasil pengujian menunjukkan gambaran tentang volatilitas harga saham pada sektor perbankan dan trading volume yang mengalami fluktuasi tajam pada masa pandemi. Oleh karena itu, hendaknya investor juga melakukan diversifikasi di real assets selain financial asset.

\section{REFERENSI}

Baret, S., dkk. (2020). COVID-19 Potential Implications For The Banking And Capital Markets Sectors. Maintaining Business And Operational Resilience. Deloitte Insights.

Bidari, A. S., dan Nurviana, R. (2020). Stimulus Ekonomi Sektor Perbankan Dalam Menghadapi Pandemi Coronavirus Disease 2019 di Indonesia. Legal Standing : Jurnal IImu Hukum, 4(1), 297305.

Chowdhury, E. K., dan Abedin, M. Z. (2020). COVID-19 Effects on the US Stock Index Returns: An Event Study Approach. Accounting, Auditing dan Accountability Journal, 1-31.

Dewi, C. K., dan Masithoh, R. (2020). JKSE and Trading Activities Before After Covid-19. Journal of Accounting and Business Management, 4(1), 1-6.

Donthu, N., dan Gustafsson, A. (2020). Effects of COVID-19 on business and research. Journal of Business Research, 117, 284289.

Elena, M. (2020). Tiga Risiko Ini Bayangi Sektor Perbankan di Masa Pandemi. https://finansial.bisnis.com/read/20200 515/90/1241123/tiga-risiko-ini-bayangisektor-perbankan-di-masa-pandemi [Diakses pada 16 Juni 2020].

Hadinata, H. (2020). IHSG turun dalam akibat corona, MAMI yakin harga akan naik lagi.

https://investasi.kontan.co.id/news/ihs g-turun-dalam-akibat-corona-mamiyakin-harga-akan-naik-lagi [Diakses pada 5 Mei 2020].

Hapsoro, D., dan Husain, Z. F. (2019). Does 
sustainability report moderate the effect of financial performance on investor reaction? Evidence of Indonesian listed firms. International Journal of Business, 24(3), 308-328.

Haryanto. (2020). Dampak Covid-19 terhadap Pergerakan Nilai Tukar Rupiah dan Indeks Harga Saham Gabungan (IHSG). Jurnal Perencanaan Pembangunan: The Indonesian Journal of Development Planning, IV(2), 151-165.

Hidayat, D., dan Topowijono. (2018). Pengaruh Kinerja Keuangan Terhadap Harga Saham (Studi Pada Perusahaan Pertambangan Subsektor Pertambangan Minyak Dan Gas Bumi Yang Terdaftar Dibursa Efek Indonesia Periode 20132016). Jurnal Administrasi Bisnis, 62(1), 36-44.

Husnan, S. (2005). Dasar-dasar Teori Portofolio dan Analisis Sekuritas. Edisi 4. Yogyakarta: Penerbit dan Percetakan UPP STIM YKPN.

Kritzman, M. P. (1994). What Practitioners Need to Know about Event Studies. Financial Analysts Journal, 50(6), 17-20.

Kusnandar, D. L., dan Bintari, V. I. (2020). Perbandingan Abnormal Return Saham Sebelum dan Sesudah Perubahan Waktu Perdagangan Selama Pandemi Covid-19. Jurnal Pasar Modal Dan Bisnis, 2(2), 195-202.

MacKinlay, A. C. (1997). Event Studies in Economics and Finance. Journal of Economic Literature, 35(1), 13-39.

Nurmasari, I. (2020). Dampak Covid - 19 Terhadap Perubahan Harga Saham dan Volume Transaksi (Studi Kasus Pada PT. Ramayana Lestari Sentosa, Tbk.). Jurnal Sekuritas, 3(3), 230-236.

Peterson, P. P. (1989). Event Studies: A Review of Issues and Methodology. Quarterly Journal of Business \& Economics, 28(3), 36-66.

Pratomo, M. N. (2020, April 1). 10 Saham Pendorong dan Penekan IHSG Pada Kuartal

I/2020. https://market.bisnis.com/read/202004 01/192/1220627/10-saham-pendorongdan-penekan-ihsg-pada-kuartal-i2020 [Diakses pada 5 Mei 2020].

Ross, S. A. (1977). Determination Of Financial Structure: The Incentive-Signalling Approach. Bell J Econ, 8(1), 23-40.

Sakti, N. W. (2020). Perekonomian Indonesia Pasca-Pandemi Covid-19. https://money.kompas.com/read/2020/ 05/10/091500226/perekonomianindonesia-pasca-pandemi-covid19? page=all [Diakses pada 11 Juni 2020].

Sansa, N. A. (2020). The Impact of the COVID19 on the Financial Markets: Evidence from China and USA. Electronic Research Journal of Social Sciences and Humanities, 2(2), 29-39.

Saputro, A. E. (2020). Analisis Harga Saham Syariah dan Volume Perdagangannya Sebelum dan Sesudah Pengumuman Covid 19. Economic \& Education Journal, 2(2), 159-168.

Suryanto, dan Muhyi, H. A. (2017). Analisis Perbandingan Volume Perdagangan Saham Sebelum dan Sesudah Stock Split di Bursa Efek Indonesia. Jurnal IImu Politik Dan Komunikasi, VII(2), 217-226.

Tandelilin, E. (2010). Portofolio dan Investasi. Yogyakarta: Kanisius.

Utami, A. T. (2017). Analisis Trading Volume Activity dan Average Abnormal Return Sebelum dan Sesudah Pemecahan Saham (Stock Split) Pada Perusahaan yang Terdaftar di Bursa Efek Indonesia. Jurnal Ekonomi dan Bisnis, 18(2), 164173.

World Health Organization. (2020). https://www.who.int/docs/defaultsource/coronaviruse/situationreports/20200226-sitrep-37-covid19.pdf?sfursn=2146841e_2 [Diakses pada 5 Mei 2020]. 